\author{
Даворин Трпески (Северна Македонија) \\ Институт за етнологија и антропологија \\ Природно - математички факултет \\ Универзитет,Св. Кирил и Методиј“- Скопје \\ е-маил: davorin777@gmail.com
}

\title{
КУЛТУРНИТЕ ПОЛИТИКИ И КУЛТУРНОТО НАСЛЕДСТВО ВО СОЩИЈАЛИСТИЧКА МАКЕДОНИЈА: ФОРМИРАҢЕТО НА МАКЕДОНСКАТА ДРЖАВА
}

\begin{abstract}
Апстракт: Во социјалистичкиот период, до 1991 година, вардарскиот дел од Македонија бил во составот на југословенската федерација, па оттука и генералната политика и културната политика се реализирале под раководство на Белград и целосно се потпирале врз идеологијата што била својствена за системот на Југославија. Секако, Македонија во тие рамки се развивала како република што имала и одредени овластувања и можела, донекаде, сама да го организира политичкиот и културниот живот, но во рамките на југословенската политика. При обидите да се најде нешто што го обработува делот на културната политика, забележително е тоа што речиси и не постојат трудови што се однесуваат само на Македонија, туку тие, пред сѐ, се однесуваат на целокупната територија на Југославија. Исто така, може да се забележи дека сѐ што постои од литературата, главно, се однесува на позитивизмот во однос на политиката и на културната политика на Југославија, но и на негативниот критицизам кон капиталистичките земји и на нивните политики.
\end{abstract}

Клучни зборови: Југославија, Македонија, социјализам, политика, наследство.

Културната политика на федеративна Југославија се базирала на социјалистичката антифашистичка револуција, а подоцна на неа се надградувала и политиката на самоуправувањето, која била одлика за југословенското социјалистичко општество. Така, како основни мислители што се среќаваат во делот на генералните политики се општоприфатените левичарски автори: Карл Маркс, Фридрих Енгелс, Владимир Илич Улјанов - Ленин, а потоа на нивните размислувања се надоврзуваат и југословенските автори, приврзаници на социјализмот: Едвард Кардељ, Борис Мајер, Бранко Прњат и други. Според овие автори, социјалистичката 
култура спаѓa во најзначајните фактори што овозможуваат навлегување на социјалистичките и хуманистичките идеи во светот. Таа, за нив, помага да се обединат хуманистичките струења на светските култури и има цел да ги приближи сите социјалистички нации. Во случајот со Југославија, социјалистичката култура имала за цел во земјата да се зацврстат соработката и братските односи меѓу народите и народностите. Вера Томиќ, истражувач на културата и културната политика во социјалистичка Југославија, нагласува дека „за нашите народи, културата претставува вредност од особено значење, која ни овозможува на светот да му ја покажеме нашата животна сила и нашите специфични идеи“ (Tomić 1969: 57). Впрочем, уште во овие рани југословенски форми на креирање на културната политика, се гледа дека се нагласени националните идеи на југословенските народи, а не на Југославија како целина. Се разбира, со донесувањето на новиот Устав на СФРЈ од 1974 година, уште повеќе се истакнала независноста на републиките во однос на централната власт и на националните идеи на народите на Југославија им се овозможило поголема слобода и изразување на националните ставови, што, на крајот, водело до целосно раздружување на југословенската држава.

Според Бранко Прњат (Prnjat 1979: 136-138), социјалистичката држава, преку победата во социјалистичката револуција, имала голема и незаменлива улога во културната преобразба на општеството. Тоа се одразува при процесот на создавањето на политичките, економските, институционалните и другите предуслови за социјалистичката културна преобразба, при дефинирањето на главните правци на културната политика. Без таквата улога на социјалистичката држава, извесно е дека не би можела да се замисли ни културната, но, исто така, ни економската преобразба на општеството. Според Прњат, тежнеењето на државата да завладее во целост со сите процеси од културата ни најмалку не претставува цел, туку е дел од напорот да се заокружи, комплетира и стабилизира еден систем. Според тоа, Прњат нагласува дека државната културна политика во дефинирањето на своите барања кон културното наследство и кон културното творештво неминовно била потребна и претставувала елемент што служи едноставно за зајакнување на системот. Истовремено, тоа морало да води и кон задушување и ограничување на едни, а максимално фаворизирање на некои други функции во делот на културата. На тој начин, државната културна политика градела такви инструменти на влијание, дејствување и насочување на културата што обезбедувале многу постабилен и многу потраен правец на одредена ориентација во културата, максимално поддржана преку економските, политичките и идеолошките мерки на државата. Сепак, она што е од особен интерес за оваа тема е начинот на организирање на културните вредности и нивните финансирања во Југославија, од 1945 година до нејзиното растурање како држава. Може да се каже дека тогаш и македонското општество, во заедница со југословенското, поминало низ неколку фази на културно организирање и финансирање (Zlatar 2001: 61):

- до 1950 година: советско административно-етатистичко 
управување и идеологија на социјалистичкото просветителство и комунистичкиот авангардизам;

- 1950 - 1975: етапна децентрализација на културата и отворање спрема западните културни влијанија; конфликт меѓу сојузните и републичките инстанци на финансирање;

- 1975 - 1990: воведување самоуправен модел на здружување во културата и финансирањето, во кој главен облик на организирање и финансирање на културните дејности е т.н. самоуправна интересна заедница (СИЗ), која се организира од локално до републичко ниво; во основа, тоа не се разликува од буџетското финансирање бидејќи двата начина се резултат на законската присила и попишување, а не на слободната размена на добра.

До околу 1950 година било применувано советско административноетатистичко управување или некаква југословенска форма на тој етиайистиички моgел (Prnjat 1979: 141) на културна политика, кој се одликувал со висока концентрација на моќ за одлучување при решавањето на одредени задачи, а кои се однесувале на социјалистичката културна изградба на земјата. Пред сѐ, тука се мисли на зајакнувањето на материјалната база за културата, развојот на институциите што биле од областа на културата, подигнувањето на општото образовно ниво на населението и сл. Имено, социјалистичката држава и нејзините органи располагале со голема економска и политичка моќ. Располагајќи со неа, државните органи ја задржале моќта во однос на секоја посебна општествена дејност, па така и во однос на културата. Таа моќ опфаќала можности за одлучувања што се однесуваат на економските, институционалните, програмските, кадровските и другите елементи од културниот развој и се спојувала со идеолошките и политичките критериуми за вреднување на културата. Зацврстувањето на државната моќ над културата придонесувала кон зајакнување на државната идеологија и на државната културна политика. Државната идеологија во областа на културата била манифестирана во барањата за создавање таква култура што ќе одговара на државните интереси, а тоа бил патот кон создавањето на државната култура.

Во годините што следувале, по 1948, а особено по 1950 година, како резултат на лошите односи на тогашната ФНР Југославија со Советскиот Сојуз, земјата полека се оддалечила од етатистичкиот модел, кој бил пресликан од советскиот, и се приближила и се отворила кон западните културни влијанија. Сепак, како главна одлика за овој период е тоа што дошло до конфликт помеѓу сојузните и републичките раководства, така што и едните и другите упорно настојувале да финансираат во културата, што, секако, било и причина повеќе да бидат направени промени и дефинирања во културата и во делот што се однесувал на нејзиното финансирање.

Самоуйравувањеӣо, одденешна гледна точка, се сфаќа како почеток на распадот на Југославија, но, тогаш, тоа со новиот Устав на СФРЈ од 1974 година (Jović 2003: 15) претставувало децентрализација на југословенското 
општество, а според тоа самоуправувањето значело децентрализација и на културната политика во Југославија. Тоа било сфатено и како важен услов за демократизацијата на земјата, проширување на општествените бази за одлучување, зголемување на културните иницијативи и создавање на културни субјекти. Со тоа, Социјалистичка Република Македонија во рамките на југословенското општество ја добила можноста за посамостојно дејствување во областа на креирањето на културната политика. Сепак, главните носечки принципи при креирањето на културната политика во Југославија ги имала Комунистичката партија на Југославија, а принципите на културната политика биле дефинирани во Програмата на Сојузот на комунистите на Југославија (Прњат 1987: 16). Културната политика на самоуправното општество, пред сѐ, била насочена кон создавање на сите оние материјални и морални услови што овозможувале исполнување на творештвото во сите области од општествениот живот, како и негова што поадекватна општествена и морална стимулација.

Кон крајот на осумдесеттите, во поранешниот југословенски систем се појавил и феноменот „псевдопазари“ (Zlatar 2001: 61-62). Впрочем, политичкиот систем не бил подготвен да го препушти одлучувањето ниту на самоуправното договарање, ниту да воспостави слободни пазарни односи. Во некои дејности се појавиле облици на независно здружување, кои, привидно, функционирале на пазарна основа.

Кога денеска се говори за културата во осумдесеттите години на XX век, најчесто се заобиколуваат елементите на финансиска и на структурна организација како помалку важни, а се истакнуваат процесите на дезидеологизација и слободни меѓукултурни размени. Културната елита на осумдесеттите ја чинеле левоориентираните либерали и граѓанските интелектуалци, кои не го носеле товарот на припадноста од националното движење во седумдесеттите. Професионалното ниво на културното производство било прилично високо, а финансиската потпора на културата, благодарение на државното печатење пари без покритие и инфлацијата, била привидно задоволувачка (Zlatar 2001: 62). Токму во такви околности југословенската култура, како и поединечните републички култури (а во таа смисла и македонската) го дочекале падот на берлинскиот sид и распадот на социјалистичкиот или комунистичкиот блок. По губењето на наднационалната идеологија, по губењето на заедничката наднационална држава, по губењето на заедничкиот југословенски културен простор, поранешните југословенски републики уште повеќе се свртиле кон себе, кон градење на самостојни, независни национални држави и создавање сопствени ставови за вредностите и идеи за некои нови национални културни политики во кои во голема мера на површина излегувале најразличните национализми, што предизвикувале и воени судири во некои од републиките.

Покрај тоа што генералните ставови во креирањето на културната политикадоаѓалеодБелград, арепубличкитеполитикибилеприспособувани кон нив, сепак, НР Македонија имала потреба да го надополни она што 
балканските земји го оствариле во изминатите педесет или сто години градењето на националните држави. Впрочем, во годините кога другите балкански земји работеле на политиките за дефинирање и зацврстување на нивниот национален идентитет, територијата на Македонија, во рамките на Отоманската Империја, била под големо влијание на соседните пропаганди, кои активно работеле. Формираните балкански држави имале изградени капацитети за таа дејност и со голем успех работеле на териториите на отоманска Турција на Балканот. Националните наративи во балканските држави започнале да се развиваат уште во текот на XIX век и во основа ја содржеле концепцијата на нацијата како една од најзначајните категории на државата. Идејата одела во насока на градењето на „нација - држава“, а со тоа и активно придонеле кон развивање на националните идеи, најпрвин во своите граници, а потоа се насочиле и надвор. Речиси во секоја од балканските држави, Македонија претставувала значаен елемент што бил сметан за нејзин составен дел. Набрзо, користејќи ги приликите, балканските сојузници ја одзеле Македонија од Турција и ја поделиле меѓу себе на нееднакви делови, т.е. поставиле арбитрарни граници низ Македонија, не земајќи го предвид етничкиот идентитет на нејзините жители (Језерник 2002: 34). Подоцна, вардарскиот дел на Македонија ја добил шансата да формира своја држава во рамките на ФНР Југославија. Токму поради ваквите општествено-историски прилики, може да се каже дека, во рамките на југословенската федерација, Македонија добила одредена можност да надополнува дел од изгубените години и интензивно да работи на дефинирањето на македонскиот национален идентитет за, притоа, „да фати чекор“ со своите соседи, спротивставувајќи им се со своја политика.

Во периодот од 1944 до 1991 година, на пример, кога вардарскиот дел на Македонија бил дел од федерацијата, настаните од минатото не само што се славеле поради нивниот национален карактер туку претставувале и чекори во еден процес за кој се верувало дека водел кон иднината. Вклучувањето на Илинден во македонскиот национален наратив било од исклучително значење, и покрај тоа што во целост не одело во прилог на идејата за Југославија и за југословенството. Сепак, според Кит Браун (Браун 2010: 8), политичарите, заедно со историчарите и со уметниците, на хероите од Илинден им ја дале улогата на претходници на панјугословенското партизанско движење (1941 - 1944). Така, Крушевската Република во рамките на федеративна Југославија се славела не само како македонска туку и како социјалистичка, но, истовремено и како југословенска, а притоа биле истакнувани егалитарните идеи на нејзините водачи. Тоа, за време на југословенскиот период, се манифестирало преку изградбата на споменици, грандиозни по својата градба, а кои имале за цел да ја величаат македонската национална борба, но, и борбата против поробувачите и угентувачите на сиромашната работничка класа. И на овој начин, ваквиот наратив мошне успешно бил вклопен во градењето на македонскиот национален идентитет. Тука особено значајно место зазема споменикот „Илинден“ или 
„Македониум“ во Крушево, преку кој биле прославувани двата Илиндена оној од 1903 и оној од 1944 година. Тој официјално бил пуштен во употреба на 2 август 1974 година, на 30-годишнината од Заседанието на АCHOM и 71. годишнина од Илинденското востание (Браун 2010: 8). Гледано од денешен аспект, наративите за Илинден и за Крушевската Република не би биле целосни доколку кон нив не би бил вклучен и главниот протагонист на македонското револуционерно движење. И покрај тоа што не бил активен чинител и учесник во Илинденското востание, сепак денес се смета за еден од најопеаните револуционери од тој период во сите делови на Македонија - Гоце Делчев.

Непосредно по завршувањето на Втората светска војна и веднаш по формирањето на македонската држава во рамките на југословенската федерација, од страна на аворитетите на НР Македонија и НР Бугарија ${ }^{1}$ било договорено моштите на овој револуционер да бидат пренесени од Софија во Скопје (1946 година) ${ }^{2}$. Ова воедно претставувало и исполнување на Заветот, напишан на бугарски јазик, врз урната со моштите што дотогаш се чувале во просториите на Илинденската организација во Македонскиот дом во Софија: „ги заколнуваме поколенијата, светите коски да бидат погребани во престолнината на независната македонска држава. Август 1923, Илинден“. Покрај тоа било договорено од Софија во Скопје да биде пренесена особено значајната документација, литература и етнографски предмети од штотуку укинатиот Македонски научен институт (1947 година). Подоцна тие претставувале основа за формирање на некои од институциите на НР Македонија, кои имале национален предзнак, а тоа се Народната и

1 Овие договори им претходеле на официјалните разговори помеѓу ФНР Југославија и НР Бугарија на Блед. Бледските разговори што се воделе во јули и август 1947 година претставувале само „круна“ на добрата соработка, кога бил отворен и пат за создавање балканска федерација. Повеќе за ова во: Peranović 1988: 191.

2 „Денес, 7 октомври 1946 година во Софија, во присуство на претставниците на Народна Република Македонија, Кирил Петрушев, министер за труд на НР Македонија, Диме Бојановски-Дизе, министер за трговија, и претседателот на Народниот фронт на Скопје, Лазар Танев, од една страна, и од друга страна Акциониот комитет за предавање на посмртните останки на Гоце Делчев, предводени од претседателот Стефан Аврамов, потпретседателот Михаил Сматракалев, секретарот Ѓорѓ́ Абаџиев и членовите Лика Чопова Јурукова, Христо Миданов, Р. Спасенов и М. Трајков, го потпишавме овој протокол за следново: Потпишаните полномошници на Народна Република Македонија од претседателот на Илинденската организација во Бугарија, Стефан Аврамов, и од раководното тело на истата организација, ги примивме чуваните мошти (од 2 август 1923 година до денес) на првоапостолот на Македонското ослободително движење и наш првоучител Гоце Делчев, за да ги поставиме во неговото вечно почивалиште, изградено во Скопје, за да бидат чувани од поколенијата на Слободна Македонија..." - содржината на Протоколот за преземање на моштите на Гоце Делчев, потпишан на 7 октомври 1946 година, од страна на претставниците на новата народна власт на Народна Република Македонија и на Илинденската организација од Софија (Димитриевски 2019). 
универзитетска библиотека „Св. Климент Охридски“ и Етнолошкиот музеј во Скопјез ${ }^{3}$.

Ликот и делото на Гоце Делчев, меѓу другите, набргу станале каментемелник врз кој се градела македонската држава, а неговите мошти, кои биле сместени во црквата Св. Спас во Скопје, станале значајни македонски национално-политички реликвии. Имено, уште при пренесувањето на моштите од Софија во Скопје и нивното (ре)погребување, гледано од аспект на антропологијата, се забележуваат елементи на една општествена драма (Микулић 2009: 93), организирана од младата македонска држава4. Исто така, просторот на црквата во Скопје веќе бил некаква референтна точка за изведување религиски обреди. Верниците уште во минатото, преку најразлични практики веќе го конституирале просторот како свет (Eliade 2003: 75). Со донесувањето на моштите на Гоце Делчев, сакрализацијата на просторот на црквата Св. Спас значително била зајакната. Тоа особено се гледа преку револуционерната дејност на Гоце Делчев насекаде во етнографска Македонија. Впрочем, неговата дејност била величана и изедначувана со ослободувањето на земјата. Исто така, тој за народот претставувал македонски првоапостол, па оттаму и неговите коски биле сметани за свети, како што е и наведено во погоре споменатиот „Завет“. Она што е уште позначајно е дека моштите биле донесени онаму каде што треба, во Македонија - земјата за која се борел. Доколку ги следиме парадигмите на Елијаде (Eliade 2003: 75-76), со тоа што моштите на Гоце Делчев се во Македонија, веќе целокупната нејзина територија може да се разгледува како простор што е свет, уреден, сигурен и познат, а опкружен со неосветен, туѓ и несигурен простор со кој владеат политики со аспираторски идеи и амбиции - идеи што политиката на федеративна Југославија успешно ги всадила, особено по исклучувањето на ФНР Југославија од Информбирото

3 Зачуван е Списокот на книгите од Библиотеката на Македонскиот научен институт во Софија, предаден од Комисијата за ликвидација на Институтот на претставниците на Народна Република Македонија, согласно со актот од 28.5.1947 година. Во Списокот, според бугарски извори, се заведени 3966 наслови на 57 листа. Исто така, 1351 етнографски музејски предмети биле ставени во 5 сандаци и биле предадени на НР Македонија, заведени на 16 листа од истата Комисија за ликвидација на Институтот (Документи 2010).

4 За пренесувањето на моштите во Скопје биле извршени посебни подготовки. Бил изработен саркофаг во резба од страна на македонскиот уметник Нестор Алексиев и била избрана посебна делегација со посебен одред за пренесување на моштите, предводен од генералот Кирил Михајловски-Груица. Во спомените на Груица, официјалната церемонија започнала во Софија. Коските, во придружба на околу 2000 Македонци, ја напуштиле престолнината на Бугарија. Саркофагот поминал низ Пиринска Македонија, а насекаде народот му оддавал последна почит на Гоце. Груица истакнал: „На пат меѓу Симитли и Петрич во едно село каде што населението беше од Кукуш, машко и женско, старо и младо, празнично облечени - легнаа наземи кога лафетот поминуваше покрај нив“ (Михајловски 1971: 6-7). Во весникот „Македонско знаме“ било напишано: „Една трогателна манифестација на еден народ, кој бил секогаш единствен во своите идеали и остана до крај верен на Гоце Делчев... Гоце мртов се соедини со својот слободен народ, во својата слободна држава..." (Македонско знаме 1946: 3). 
во 1948 година (Peranović 1988: 200-201). Уредениот или космизираниот свет на територијата на моштите се смета за „наш свет“, додека категоријата на несветото, на неуреденото и на хаотичното е именувана како „друг свет“" (Eliade 2003: 75-76). Ваквите политики на Југославија, по нејзиното исклучување од Информбирото, особено биле водени кон НР Бугарија, која веќe целосно започнала да ја менува политиката кон Македонците во Пиринска Македонија.

Националните културни политики во НР Македонија продолжиле и во наредниот период. Биле формирани низа национални институции. Се разбира, и покрај тоа што во одредена мера некаква „блага“ форма на национализам била толерирана и била поддржувана, сепак, треба да се нагласи дека многу работи што се поврзани со македонската национална политика биле задушени и цензурирани од страна на Комунистичката партија на Југославија и од страна на Комунистичката партија на Македонија. Моделот за поврзување на левичарското наследство од илинденскиот период со идеите од периодот на НОБ довел до воздигнувањето на Илинденското востание и на револуционерната борба од тој период, предводена од Гоце Делчев, на едно национално ниво и овозможил засилено градење на македонска национална политика во периодот што следел.

\section{Литература}

Браун, Кит. 2010. Минайоӣо ӣog ӣрашање. Моgерна Макеgонија и неизвесносиииее на нацијайа, Скопје.

Димитриевски, Предраг. 2019. „Дали 7 октомври лета во балонот на Илинденска Македонија“, pressingtv од 19.6.2019: https://pressingtv. $\mathrm{mk} /$ makedonija/dali-7-oktomvri-leta-vo-balonot-na-ilindenska-makedonija/ (пристапено на: 24.8.2019).

Документи. 2010. „Документи за ликвидирането на македонския научен институт“, https://www.sitebulgarizaedno.com/index.php?option=com_content\&view =article\&id =237:-1941-1947\&catid=29:2010-04-24-09-14-13\&Itemid=61 (пристапено на: 23.8.2019).

Језерник, Божидар. 2002. „Македонци: сомнителни заради нивното отсуство“, ЕйноАнйройоЗум 2: 30-8о.

Макеgонско знаме. 1946. София. 
Микулић, Татјана. 2009. „Концепт 'друштвене драме’: сахрана Зорана Бинђића“, Antropologija 9: 73-88.

Михајловски, Кирил. 1971. „Силно е македонското чувство“, Скопје: Млаg борец.

Прњат, Бранко. 1987. Синдикай и осииваривање циљева кулйурне йолишиике. Београд: Институт за политичке студије.

Eliade, Mircea. 2003. Sveto i profano, Novi Sad - Sremski Karlovci: Izdavačka knjižarnica Zorana Stojanovića.

Zlatar, Andrea. 2001. „Kultura u tranzicijskom periodu u Hrvatskoj“, Reč 61(7): $59-74$.

Jović, Dejan. 2003. Jugoslavija - država koja je odumrla: Uspon, kriza i pad Četurte Jugoslavije (1974-199o), Beogra: Prometej, Zagreb i Samizdat B92.

Peranović, Branko. 1988. Istorija Jugoslavije, 1918 - 1988, knj. III, Beograd: Nolit.

Prnjat, Branko. 1979. Kulturna politika, Beograd: Radnička štampa.

Tomić, Vera. 1969 Kulturna politika II, Beograd: Zavod za proučavanje kulturnog razvitka. 